\title{
On Self-Revelation and Research
}

\author{
BERNARD RICCA
}

St. John Fisher College, (USA)

You never finish research; you merely abandon it.
- Gabriel Weinreich (personal communication)

The readers of Complicity will be, for the most part, well versed in the way the research game is played, and will, probably better than me, know how to work through academic writings. Accordingly, I would like to provide a different lens through which to interact with the texts of this Special Issue.

The Feature Article, (Re)Imagining teacher preparation for conjoint democratic inquiry in complex classroom ecologies, began as a symposium at the 2010 Annual Meeting of the American Educational Research Association and was re-crafted into a single article for presentation here. On the program were papers by the authors of the Feature Article and responses by Bill Doll and Sherrie Reynolds. However, to say "began" is actually incorrect in a larger sense, although it is correct according to the rules of academic writing. The "beginning" can be traced back through the submission process, to some prior conversations in which the authors took part, and to at least their own primary school experiences, some of which are recounted in the Feature Article. However, even that would not take us to the "beginning". Although it would probably be safe to say that it takes us to the point where the authors first encountered the story, the story would have to be traced back through the people and cultures that created the schooling that were encountered by the authors, and, well, I think we can agree that the "beginning" is difficult. In fact, I think that perhaps not only do we never finish research, we never begin it either.

As complexivists, we know both the difficulties and pitfalls of attempting to disentangle an entity from its past and its connections; that we never begin research may come as no surprise to the readers of Complicity. However, this means that we only present a finite amount here (limited by the time and space available to those who converse) and we may miss the infinity. This is the nature of the research game. However, in a very real sense, 
the apocryphal stories of "primitive" peoples who believe that if-you-take-my-picture-yousteal-my-soul may be an important caution to us: The snapshots presented here can be read without the person of the author attached. This is the nature of the research game, and (to steal from Bill Doll who I believe was taking from Whitehead), while I'm not opposed to good research, I am afraid of it.

I bring all this up because putting something down in text has permanence to it that only makes sense when combined with the flux that lead to it. In fact, I think that the permanence is already connected with the flux (Whitehead, 1979); it is the nature of the academic game that causes us to pretend the inseparable are separated. And so, we need a different lens through which to speak with and listen to our conversation'1.

Martin Buber (1966) begins his work The Way of Man with a story that revolves around the Biblical question "Where are you?" The question, as Buber saw it, was asked not because God was lacking in knowledge. Instead of asking for a location, the question says "Where are you in your world? So many years and days of those allotted to you have passed, and how far have you gotten in your world?" (Buber, 1966, p. 10). In other words, God was asking for self-revelation, an account of where Adam had gotten to so far. This - selfrevelation - is, I believe, an important lens through which to converse, and it is that lens that I offer to those who would participate in the conversation here.

The Feature Article deals extensively with self-revelation. The authors reveal themselves, as they were as students and as they are now. While the piece can be seen merely as making an academic case for change in teacher preparation, I would encourage the reader to examine it in a different manner: The authors have also revealed how far they have travelled in their allotted years. Further, it shows some of the ways in which their selfrevelation has been and is used by others. Sadly, self-revelation is not always treated respectfully in our schools. Additionally, while the responses to the Feature Article can be read as academic pieces, those authors also undertake self-revelation prompted by the selfrevelation of the lead authors. I also hope that readers will recognize that their own responses can be read as acts of self-revelation. (I also hope that readers will recognize my own self-revelation in my choice of how to frame this Special Issue. ${ }^{2}$ What is written here probably says as much about this author as it does about the other authors.)

I would like to note the personal nature of such self-revelation here. This issue is not attempting to be "correct" or "true" in some objective manner. (It is, however, good that the authors all recognize their relationships to the larger community of researchers and so are not merely engaging in the sort of self-exhibition that has been popular on American television shows.) We can read even the critiques of the Feature Article as self-revelatory; each author reveals something personal about her- or him-self, and to fail to recognize that is to fail to recognize the importance of the writings (and the writers). It is our failure to

\footnotetext{
${ }^{1}$ As Weinreich and I are both acousticians, I feel qualified to remind/inform the reader that there are such things as acoustic lenses even though it is common to think only of the optical type. One might be familiar with the "whispering room" which is a popular exhibit in many science museums. In these rooms, the shape of the room enables two people to converse by whispering, even though they are separated by a great distance. This is an acoustic mirror, akin to an acoustic lens.

${ }^{2}$ As befits a journal that deals with complexity, this sort of recursive happening is appealing.
} 
recognize the personal in all self-revelations - whether those self-revelations be writings in an academic journal or our behaviors as students in elementary schools - that I believe Seltzer-Kelly et al. are calling to our attention.

Deborah Osberg (2009), in the first Special Issue of Complicity quoted David Weinberger (2005) who wrote:

Knowledge is not the body of beliefs that needs no further discussion. Knowledge is the never ending conversation. And much of that conversation is precisely about what we can disagree about and still share a world.

Notice that Weinberger talks about the participants, not the writings, "shar[ing] a world". I believe that looking through a lens of self-revelation allows us to recognize the other (and our selves!) and participate in the conversation.

Although there are many places where I believe the lens of self-revelation are important in this issue, I will bring to your attention only two. First, in the self-revelations of Shannon and Serina in the Feature Article we have an account of what happens when the selfrevelation of a story is mistaken for the whole story history. When students' stories are divorced from relationships, educators can mistake a snapshot for the whole, thereby labeling students and, ultimately, dismissing them. The self-revelation that children give to us almost every day often is used against them.

As a second example, Gershon has much to say about the use of ethnography in the Feature Article. None of the eight (Eight?! What were we thinking?) reviewers said anything about these points within ethnography. Hence, we can approach the pieces academically and ask if the Feature Article represents "reality" (or perhaps "mis-represents" it if it fails to match Gershon's flavor of ethnography?). We can approach Gershon's piece with the same academic lens. However, we can also look through the lens of self-revelation, and hear the stories of Seltzer-Kelly et al. and of Gershon as answers to Buber's "Where are you?" I think that only the lens of self-revelation allows us to hear both the permanence and the flux.

It is not, co-incidentally, only the infinite past that is missing in the accounts here; we are also missing the future of the accounts put forth. As the future is "real, but not actual" (Whitehead, 1979, p. 214) we must therefore recognize the limited nature of all that we say. Further, the so-called "butterfly effect" reminds us that it is difficult to tell the trivial from the important, as the "size" of causes may not match the "size" of their effect, and so we do not know what is "really going on" in these writings. "We never finish research, we merely abandon it." 3

Hence, the danger for all of us is that we might accept the permanence of what is written without keeping the (unstated) flux also in the foreground, and thereby fail to hear the writers as we read the writings. I hope that we all will hear the writers.

\footnotetext{
${ }^{3}$ Len Waks made an interesting statement to me while I was in the midst of this. It was in the body of the e-mail: "If I had more time I'd fuss with it more, but I doubt this would actually improve it" (Waks, personal communication). Abandoning research might not be entirely bad.
} 


\section{References}

Buber, M. (1966). The way of man: According to the teaching of Hasidism. Seacaucus, NJ: Citadel Press.

Osberg, D. (2009). "Enlarging the space of the possible" around what it means to educate and be educated. Complicity, $6(1)$, i-x.

Weinberger, D (2005). Knowledge as conversation. http://www.hyperorg.com/blogger/2005/08/22/knowledgeas-conversation/ (Retrieved 22 February 2011).

Whitehead, A. (1979). Process and reality (corrected edition). New York, NY: Free Press.

(C) Copyright 2011. The author, Bernard Ricca, assigns to the University of Alberta and other educational and non-profit institutions a nonexclusive license to use this document for personal use and in courses of instruction provided that the article is used in full and this copyright statement is reproduced. The author also grants a non-exclusive license to the University of Alberta to publish this document in full on the World Wide Web, and for the document to be published on mirrors on the World Wide Web. Any other usage is prohibited without the express permission of the authors. 